\title{
Landslides and Their Contribution to Land-cover Change in the Mountains of Mexico and Central America ${ }^{1}$
}

\author{
Carla Restrepo ${ }^{2}$ and Nora Alvarez ${ }^{3}$
}

Department of Biology, P.O. Box 23360, University of Puerto Rico-Rio Piedras, San Juan, Puerto Rico 00931-3360, U.S.A.

\begin{abstract}
Landsliding is a natural process influencing montane ecosystems, particularly in areas with elevated rainfall and seismic activity. Yet, to date, little effort has been made to quantify the contribution of this process to land-cover change. Focusing on the mountains of Mexico and Central America (M-CA), we estimated the contribution of landsliding to land-cover change at two scales. At the scale of M-CA, we classified the terrain into major landforms and entered in a GIS historical data on earthquake- and rainfall-triggered landslides. At the scale of the Sierra de Las Minas of Guatemala, we investigated Landsat TM data to map rainfall-triggered landslides. During the past $110 \mathrm{yr},>136,200$ ha of land in the mountains of M-CA have been affected by landslides, which translates into disturbance rates exceeding 0.317 percent/century. In Sierra de Las Minas, rainfall associated with hurricane Mitch affected 1765 ha of forest, or equivalently, landslides triggered by storms of this magnitude transformed between 0.196 (return time of $500 \mathrm{yr}$ ) and 1.290 (return time of $75 \mathrm{yr}$ ) percent of forest/century. Although landsliding results in smaller rates of land-cover change than deforestation, we hypothesize that it has a stronger impact on ecosystems, both in qualitative and quantitative terms, given its influence on vegetation and soil. Moreover, interactions between landsliding and deforestation may be altering the expression of this complex process such that the few protected areas in the mountains of M-CA may represent the only possibility for the conservation of this process.
\end{abstract}

\section{RESUMEN}

Los deslizamientos de tierra representan un fenómeno natural que afecta a todos los ecosistemas montañosos, particularmente aquellos que se encuentran en áreas de elevadas precipitaciones y actividad sísmica. Sin embargo, hasta el presente los esfuerzos por cuantificar la contribución de este proceso a cambios de cobertura de suelo han sido limitados. Enfocados en las montañas de México y Centro America (M-OA) estimamos que la contribución de los deslizamientos de tierra con cambios de cobertura de suelo a dos escalas. A la escala de M-CA, clasificamos el terreno basado en clases mayores de relieve e incluímos datos históricos de sismos y tormentas que han provocado deslizamientos de tierra en un SIG. A la escala de la Sierra de Las Minas en Guatemala, investigamos datos Landsat TM para identificar y localizar deslizamientos de tierra disperados por lluvia. Durante los últimos 110 años $>136,200$ ha de tierra han sido transformados por deslizamientos de tierra en las montañas de M-CA, lo que se traduce en tasas de perturbación $>0.317$ por ciento/siglo. En la Sierra de Las Minas, las lluvias asociadas con el huracán Mitch transformaron 1765 ha de bosque, lo que es equivalente a tasas de perturbación por deslizamientos de tierra entre 0.196 (tasa de retorno de 500 años) y 1.290 por ciento/siglo (tasa de retorno de 75 años). A pesar de que las tasas de cambio de cobertura vegetal por deslizamientos son menores que las causadas por deforestación, hipotetizamos que tienen un mayor impacto en estos ecosistemas tanto en términos cualitativos como cuantitativos por su influencia sobre la vegetación y el suelo. Además, interacciones entre los deslizamientos de tierra y la deforestación podrían estar afectando la expresión de este complejo proceso de tal forma que las pocas áreas montañosas de México y Centro América que están protegidas representan la única posibilidad para la conservación de este proceso.

Key words: Central America; land-cover change; landslides; Mexico; tropical mountains.

CONVERSION OF FORESTS TO MANAGED ECOSYSTEMS is considered a major activity impacting the carbon cycle (Houghton et al. 1998, Schimel et al. 2001). Many studies have emphasized land-cover and land-use change in lowland tropical areas, given their large areal extent and consequently, potential effect at a global scale (Melillo et al. 1996). Tropical mountains representing $<25$ percent of the Earth land surface have often been overlooked in these studies, yet they may play an unappreciated role in regional, and perhaps global carbon budgets. Deforestation has been, and still is, a prevalent process transforming these ecosystems (Ochoa-Gaona \& GonzalezEspinosa 2000, Munroe et al. 2002). Yet, a combination of steep topography, heavy rains, and seismic activity results in landsliding, a process transforming land cover in qualitatively and quantitatively different ways. Unlike deforestation, landsliding results in the removal of soil and weathered bedrock in addition to vegetation (Zarin \& Johnson 1995a,b).

\footnotetext{
${ }^{1}$ Received 16 June 2005; revision accepted 27 October 2005.

${ }^{2}$ Corresponding author; e-mail: crestre@cnnet.upr.edu

${ }^{3}$ Current address: Departamento de Recursos Naturales y Ambientales, San Juan, Puerto Rico, U.S.A.
}

Changes in land-cover associated with landsliding differ in other ways from deforestation. First, landsliding is a rapid process, whether triggered by precipitation, seismic events, or both (Thomas 1994). This translates into abrupt, and sometimes extensive, changes in land-cover, depending on the location and magnitude of the triggering event. Second, each triggering event can result in populations of tens to thousands of landslides exhibiting an enormous variability in size (Stark \& Hovius 2001). This variability in size may have profound consequences for ecosystem recovery, since "patch size" influences rates of ecological processes (Pickett \& White 1985). Lastly, landslides can affect ecosystems in irreversible ways in areas where bedrock is underlain by soils derived from volcanic ash. The removal of ash-derived soils may expose substrates that differ greatly in composition, influencing the recovery of ecosystems (Restrepo et al. 2003).

Landsliding is a complex process that can be strongly influenced by attributes of the vegetation (Sidle et al. 1985). Therefore, changes in land cover and land use resulting from human activities and climate can interact with landsliding to influence the large-scale dynamics of montane ecosystems (Diez et al. 1996, Glade 2003). 
This may explain why landslides have become an increasing hazard to human lives and infrastructure in densely populated mountains (Dai et al. 2002), and why extensive landsliding in protected tropical mountains has been treated as major ecological disasters (Figueroa et al. 1987). On the other hand, landsliding can modify land cover, but to date, there have been limited efforts to quantify this effect.

Focusing on the mountains of Mexico and Central America (M-CA), we take a twofold approach to evaluate the role of landsliding in land-cover change. First, we examine historical data on landslide-triggering events and the total area of land transformed by landslides, to provide a regional estimate of land-cover change associated with landsliding. Second, we examine remotely sensed data for a single landslide-triggering event, to establish its usefulness in evaluating and monitoring land-cover change associated with landslides at local scales. Ultimately, the combination of both approaches will help us gain a better understanding of the large-scale dynamics of tropical mountains mediated by landsliding.

\section{METHODS}

STUDY SITE.-Our study area comprises M-CA, a region characterized by an enormous diversity of life-forms and forest types, resulting from its latitudinal position, and unique tectonic, geological, and biogeographical history (Weyl 1980, Darwin \& Welden
1992; Fig. 1a). This region is representative of many others found in tropical and subtropical areas around the world that, in addition to being tectonically active, are subjected to precipitation events of variable intensity (Fig. 1b). In the past, interactions among the several tectonic plates that meet here originated the main topographic features observed today (Weyl 1980, Ferrusquia-Villafranca 1993). Currently, interactions among the same plates are the source of the many shallow earthquakes that trigger landslides across the region (Bommer \& Rodriguez 2002). Several mountainous systems are recognized in M-CA, each having a different origin, age, geology, and climate (Weyl 1980, Ferrusquia-Villafranca 1993). This variation is likely to influence ecosystem attributes and the formation of landslides within each mountainous system. In this article, we use the term "landslide" in a broad sense to describe the usually fast movement of vegetation, soil, saprolite, and rock under the influence of gravity, which results in patches of bare ground with variable characteristics. It is important to emphasize that gravity determines the downslope movement of material from hillslopes (Thomas 1994).

We focused on the Sierra de Las Minas to investigate the impact of landsliding on land cover at a local scale (Fig. 1c). This mountain system in eastern Guatemala with elevations up to $3015 \mathrm{~m}$ above sea level is one of the several subparallel high ranges comprising the Northern Sierras of Central America (Weyl 1980). It harbors an enormous diversity of species and vegetation types, and it was declared a Biosphere Reserve in 1990 .The Sierra de Las Minas

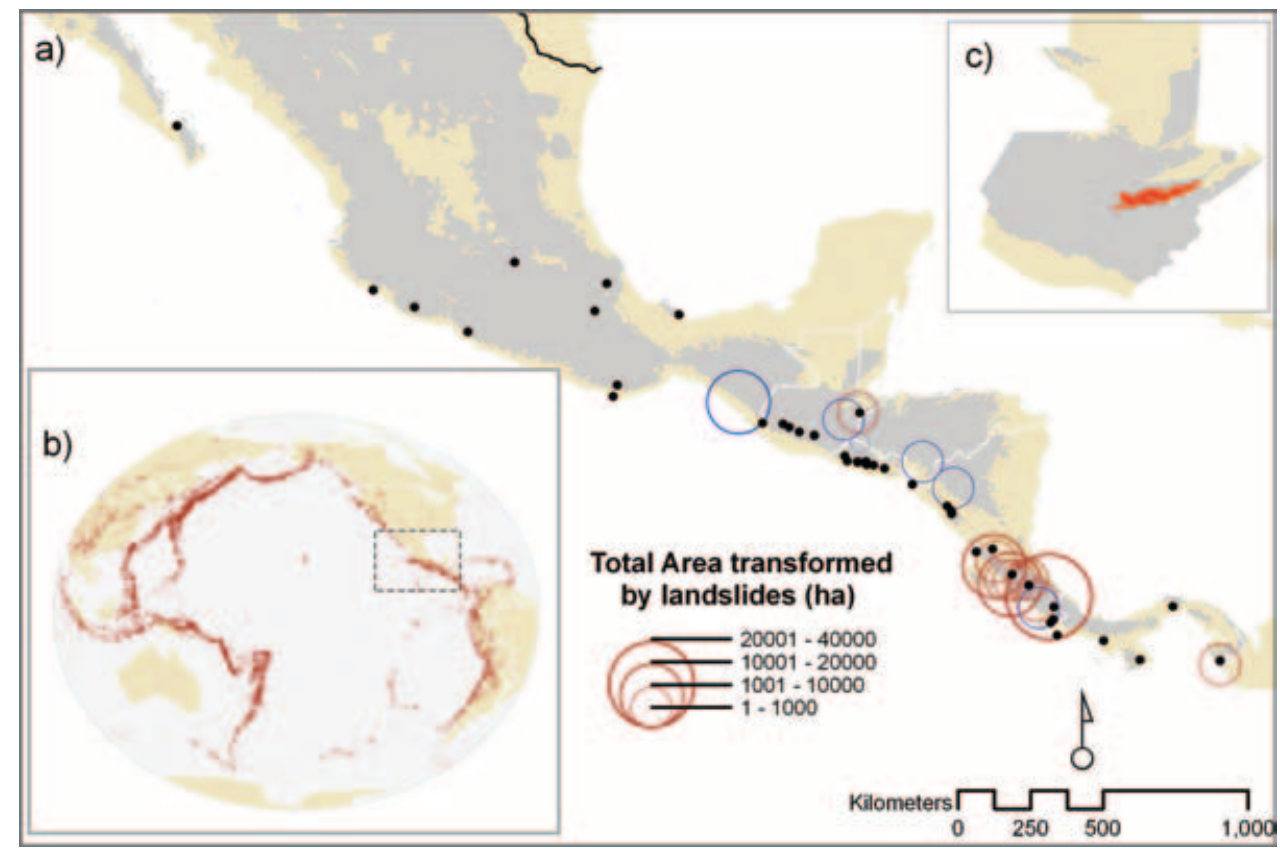

FIGURE 1. (a) Mexico and Central America lie within one of the most (b) active seismic zones in the world (small red points are earthquakes). In particular, the convergence of several tectonic plates is the source of the many shallow earthquakes that trigger landslides across the region (red circles in a); M-CA is also influenced by storms of variable magnitude, which can generate extensive landslide activity (blue circles in a). The size of the circles denotes the total area covered by landslides ( $a$ in Eq. (1)); landslide-triggering events for which this information is unavailable are shown as small black points. (c) In the Sierra de Las Minas, a small mountain range in eastern Guatemala (shown in red), earthquake- and storm-triggered landslides have left a strong imprint on the landscape. In (a), Mexican and Central American hills and mountains are in gray. 
is flanked to the north and the south by the Polochic and Motagua faults, respectively, two important sources of seismic activity in M-CA, and therefore of landslide activity (Weyl 1980, Harp et al. 1981). The Motagua fault, in particular, is where the Caribbean and North American Plates meet. In addition to earthquakes, the Sierra de Las Minas can also be affected by intense precipitation events associated with tropical storms and hurricanes, such as Hurricane Mitch in October-November 1998 (Bucknam et al. 2001). Rains of this magnitude, in combination with soils derived from metamorphic and Ultrabasic rocks, may explain the elevated number of landslides that were recorded in the Sierra de Las Minas in 1998. Strong winds seemed to have had a negligible effect in the Sierra de Las Minas due to the trajectory followed by Hurricane Mitch in M-CA (F. Hernandez, pers. comm.).

REGIONAL IMPACT OF LANDSLIDES ON LAND-COVER CHANGE.-To evaluate the contribution of landslides to land-cover change, we followed a three-step procedure. First, we classified M-CA into major relief classes or landforms. This not only depicted areas more susceptible to landslides, but also constrained our study area for the purposes of calculating disturbance rates (see below). We used a classification scheme based on digital elevation data, which combines elevation and terrain roughness to define major landforms (Meybeck et al. 2001). We derived an index of terrain roughness, representing the difference between the maximum and minimum elevation within a $60 \times 60$ cell neighborhood divided by the neighborhood's radius, using the GTOPO $30 \mathrm{DEM}$ (resolution $0.5 \mathrm{~min}$ or $c a 1$ $\mathrm{km}$; http://edcdaac.usgs.gov/gtopo30/gtopo30.asp). The elevation and terrain roughness maps were reclassified using Meybeck et al.'s
(2001) classes, and used in a matrix analysis to yield a thematic map showing the coincidence of two input classes. The unique combinations of roughness and elevation define major landforms in this new thematic map (Table 1).

Second, we estimated human population size per landform. This opened the possibility to discuss the extent to which human activities and landsliding may interact. We used the Population of the World (GPW2) grid map, in which the values of each cell (resolution $\sim 4.5 \mathrm{~km}$ at low latitudes) represent the estimated population size for the year 1995 (Ciesin et al. 2000). This map was used in combination with a rescaled version of the landform map that matched the resolution of the population grid in a matrix analysis. This resulted in a new thematic map depicting the population of M-CA per landform.

Finally, we gathered historical data from published and unpublished reports to build a data base of earthquake and rainfall events known to have triggered landslides in M-CA, and entered it in a GIS. The data base covers $c a 110 \mathrm{yr}$ and includes information on (1) characteristics of the triggering events (date, location, type, magnitude); (2) characteristics of the areas impacted by landslides (geological substrate and ecoregion); and (3) characteristics of landslides (total area over which landslides were triggered, total area covered by landslides, total number of landslides, statistics of landslide size). Most of this information has been generated in response to local and regional landslide-triggering events that have impacted directly or indirectly human populations and their infrastructure, including protected areas. We believe that the inventory of earthquakes known to have triggered landslides is relatively complete, in part because of a recent comprehensive inventory of earthquakes

TABLE 1. Landforms of Mexico and Central America. Numbers indicate extent of landform in $\mathrm{km}^{2}$ for M-CA (parentheses and regular font), CA (square brackets and regular font), and population size (italics). In gray are landforms included as mountainous terrain in the context of this study. Classification based on Meybeck et al.'s (2001) scheme.

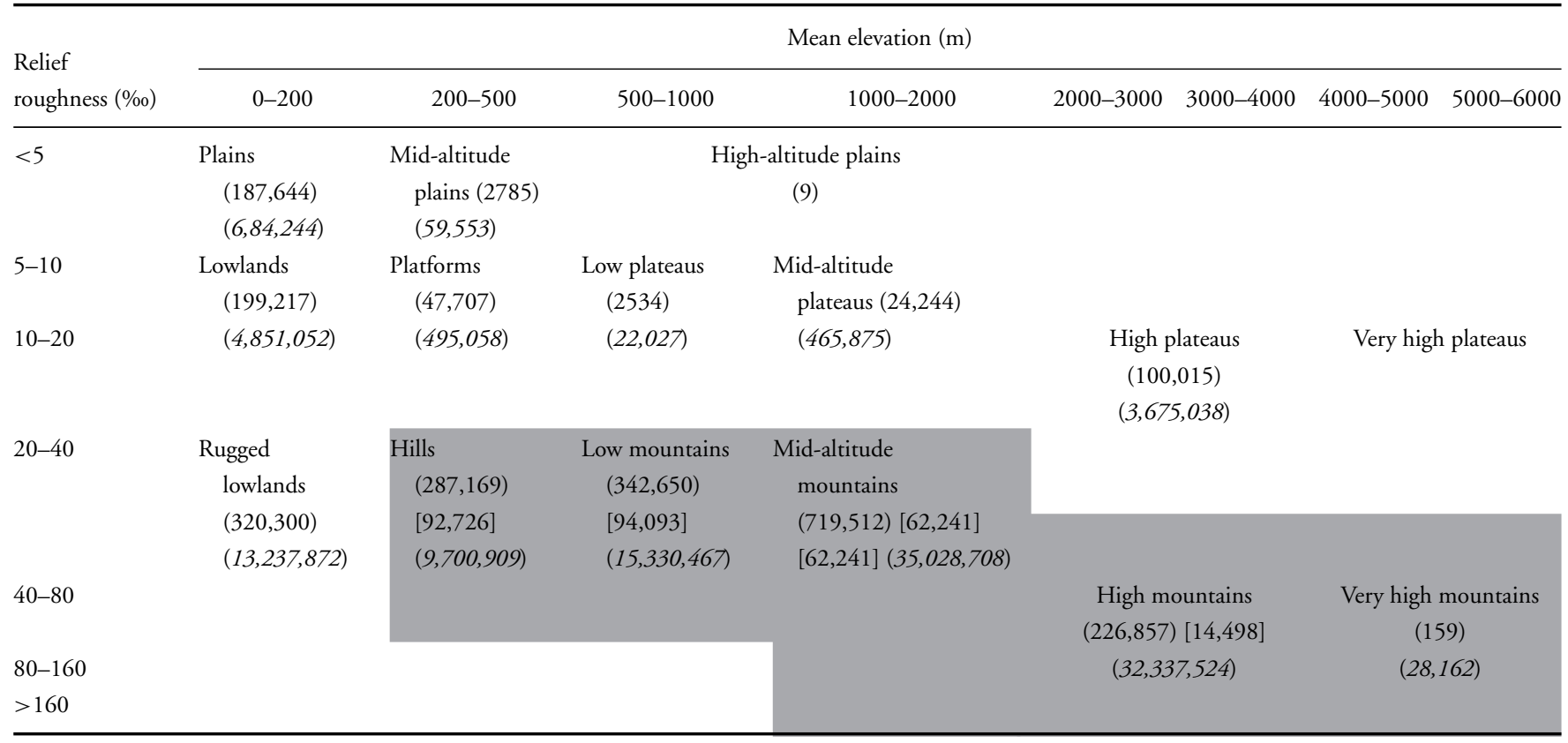


known to have triggered landslides in this region during the last ca 500 yr (Bommer \& Rodriguez 2002). On the other hand, the inventory of rainfall events known to have triggered landslides is incomplete, in part reflecting the rainfall's more local character and therefore accessibility of information. Combining historical data of different qualities and biases may seem of limited use in ecological studies; yet it is one of the few methods available for landscapechange studies (Bürgi 2004). To determine the extent to which landslides have transformed land cover per major ecosystem types, we used the "major habitat types" category of the World Ecoregion digital map (Olson et al. 2001).

LOCAL IMPACT OF LANDSLIDES ON LAND-COVER.-We used two Landsat TM images taken within 20 mo of Hurricane Mitch (Path 19 Row 50 of 3/28/2000 and Path 20 Row 50 of 12/30/1999; Fig. 2a) to evaluate the local impact of rainfall-induced landslides on land-cover in the Sierra de Las Minas, Guatemala. These images were purchased with a radiometric, geometric, and precision correction for which ground control points and a digital terrain model had been used to improve the satellite model and remove inaccuracies resulting from local terrain elevation. In addition, we performed an absolute atmospheric correction based on the dark object substraction approach (Chavez 1988) and reprojected the images to the Universal Transverse Mercator system (zone UTM 16) on the WGS 84 datum to fit complementary GIS coverages used in the classification. The two satellite images were subset using a GIS coverage depicting the hillslope and fluvial areas impacted directly and indirectly by landslides prior to the classification.

To classify landslides in Sierra de Las Minas, we followed a three-step approach. First, we masked out from the images clouds and cloud edges, and all pixels with slopes below $15^{\circ}$. Clouds and cloud edges were eliminated from the images through the collection of training sets on these features and the assignment of a value of zero to the corresponding pixels so that they would not be included in future calculations. In the Sierra de Las Minas, only 4 percent of the landslides that were triggered by Hurricane Mitch occurred in slopes below $15^{\circ}$ (Bucknam et al. 2001). In addition, most of these pixels corresponded to agricultural areas in floodplain features, including alluvial fans, which are spectrally similar to landslides and therefore could influence the accuracy of the supervised classifications. We used NASA's SRTM DEM (resolution $\sim 90 \mathrm{~m}$; http://srtm.usgs.gov/) to create a binary map showing slopes above or below $15^{\circ}$ (Fig. 2b,c), and masked out the pixels in slopes below $15^{\circ}$.

Second, we selected a pilot study region (PSR) in the Sierra de Las Minas, where the USGS had identified an elevated number of landslides (Bucknam et al. 2001) to evaluate the performance of two factors, degree of landscape heterogeneity and different band combinations, on image classification. In tropical mountains, gradients in temperature and precipitation translate into changes of vegetation over short distances (Kappelle \& Brown 2001), and this heterogeneity may influence the detection of landslides. We run the supervised classifications on the PSR which encompassed six forest types after eliminating slopes below $15^{\circ}$ (heterogeneous landscape; 251,207 ha), and one area of Tropical evergreen seasonal mixed al- timontane forest (homogeneous landscape; 14,900 ha; TESMAF). Information on forest types came from the Ecosystems Map of Guatemala (TECSULT Foresterie Inc. 2000).

We used three band combinations to explore their ability to recognize landslides in the heterogeneous and homogeneous landscapes. These included (1) bands 1-5 and 7; (2) Normalized Difference Vegetation Index (NDVI), and Texture for bands 1 and 2; and (3) bands 2, 4, 5, and three band ratios (TM 5/7, 5/4, 3/1). From now on, we will refer to the third combination as the 2, 4, 5, mineral composite treatment. The NDVI enhances the greenness reflectance differences between vegetation and bare land, and the texture enhances variability among pixels, and therefore differences between cover types (Schott 1997). The texture metrics used in this study characterized the variance around each pixel in a $3 \times 3$ neighborhood. The combination of NDVI with the Texture for bands 1 and 2 was successfully used to identify landslides of different ages on infrared aerial photographs (Restrepo et al. 2003). Bands 2, 4 , 5 have been shown to visually capture subtle differences in spectral signature between landslides of different ages and vegetation in the mountains of Bolivia (Blodgett 1998). Moreover, these were used to collect training sets and run a supervised classification on bands $1-5$ and 7 aimed at mapping landslides in the mountains of Argentina (Paolini et al. 2002). Mineral ratios are widely used in geological studies, because they readily map onto field and laboratory spectrometer measurements and they reduce brightness effects associated with topographic slope and aspect effects (Rajesh 2004). Three band ratios have been useful for displaying and distinguishing between clays and micas (TM5/7), ferrous (TM5/4), and iron oxides and hydroxides (TM3/1) minerals, plus vegetation (Carranza $\&$ Hale 2002, Rajesh 2004). The underlying geology of the Sierra de Las Minas includes minerals of these types (Harp et al. 1981).

We ran a supervised classification of the images using the Maximum Likelihood classifier (Schott 1997). The satellite images were visually interpreted (Fig. 3) to collect training sets representative of forests, shrublands, pastures, crops, water, landslides, vegetated landslide scars, and fire scars for both the PSR and the TESMAF regions. We used black and white aerial photographs $(1: 40,000)$ taken between January and March 2000 (Fig. 2d), a digital map of Guatemala forest types (http://www.ccad.ws/documentos/ mapas.html), and a GIS coverage of landslides triggered by Hurricane Mitch in Guatemala (Bucknam et al. 2001, Fig. 2e) to help the visual interpretation of the satellite images. The accuracy of the location of landslides in the GIS coverage was within 50-100 $\mathrm{m}$, which often translated into a lack of overlap between the landslide polygons and the landslides seen on the satellite images. In these cases, we gathered the training sets from the closest elongated forest clearing that because of its morphology was indicative of a landslide. To assess the accuracy of the classifications, we recoded the PSR and TESMAF classified images in two classes of interest, landslides and nonlandslides areas. From each of the recoded images, we randomly selected an average of 50 (TESMAF) and 200 (PSR) points and compared their cover type with that seen in the original satellite images (Fig. 2a), aerial photographs (Fig. 2d), and the landslide GIS coverage (Fig. 2e). Based on this selection, we estimated the producer's, user's, and overall accuracy and Kappa 

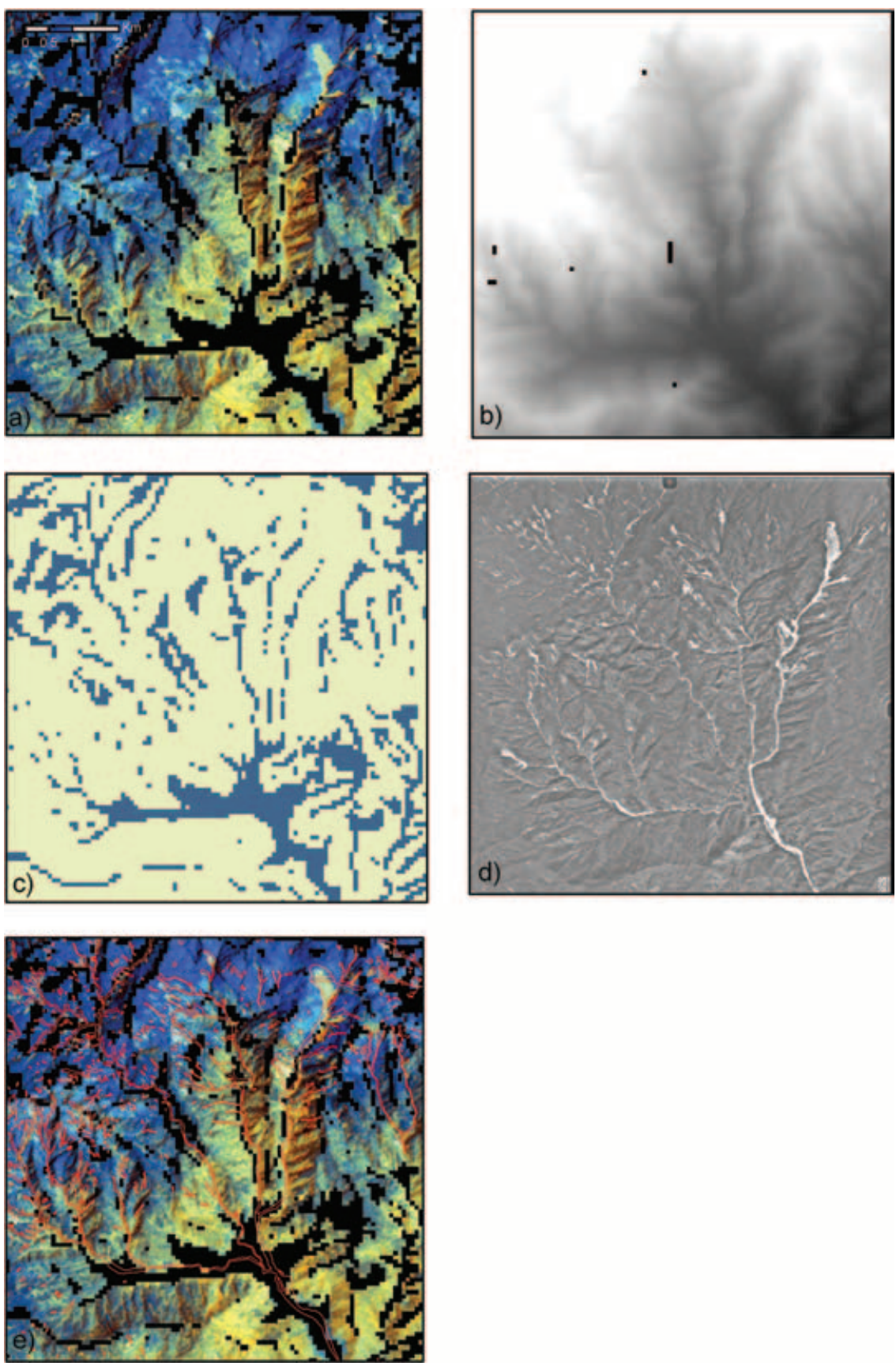

FIGURE 2. (a) The analysis of Landsat TM images may provide useful information to study landsliding at local and regional scales (RGB: 5/4, 5, 4). Ancillary information, such as (b) a DEM to segment the images into (c) slopes $<15^{\circ}$ and $\geq 15^{\circ}$, was used in combination with (d) aerial photographs taken after Hurricane Mitch, and (e) published landslide coverages to classify the images.

coefficients (Congalton \& Green 1999). Finally, we used the band combination $\mathrm{x}$ landscape heterogeneity treatment that resulted in the highest overall accuracy, and Kappa coefficient to classify the Sierra de Las Minas and obtain an estimate of the total area covered by landslides. The two scenes were classified separately to minimize errors due to different atmospheric conditions.

IMPACT OF LANDSLIDING ON LAND-COVER CHANGE.- The impact of landslides on ecosystems have traditionally been evaluated in terms of disturbance rates $(D)$, which is the extent of land denuded by landslides over a given period of time:

$D=(a / A) \times \frac{1}{t} \times 100$

where $a$ is the total area covered by landslides, $A$ is the total area over which landslides are recorded after a given landslidetriggering event, and $t$ is the time elapsed between periods of observation or triggering events, usually expressed on a per-century basis 

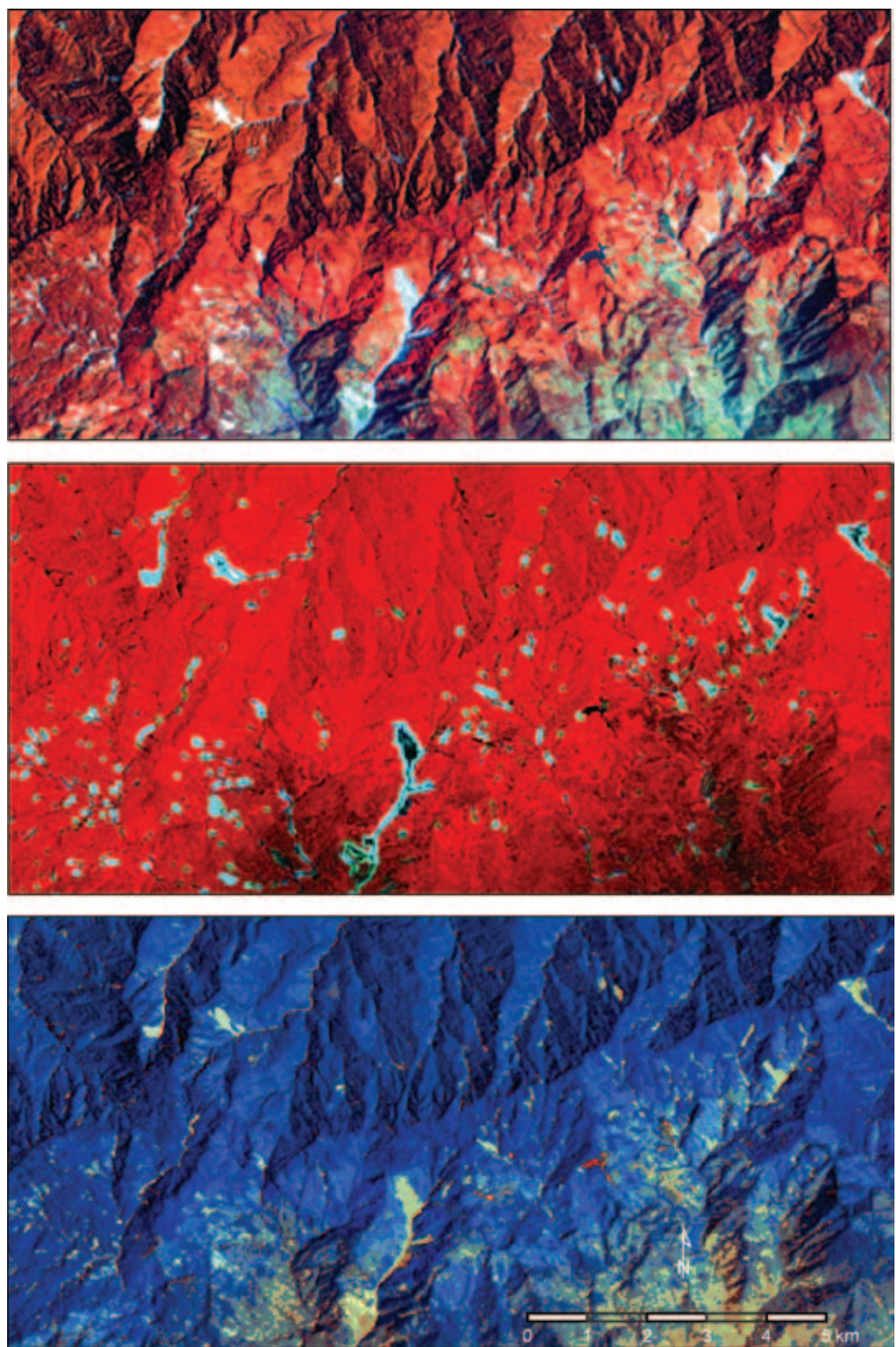

FIGURE 3. Different band combination treatments were used to visually inspect and classify the Landsat images. (a) Bands 1-5 and 7 (RGB: 4, 5, 3), (b) NDVI and Texture for bands 1 and 2 (RGB: NDVI, T2, T1), and (c) Bands 2, 4, 5, and mineral composite (RGB: TM 5/4, 5, 4).

(Gardwood et al. 1979). In this regard, disturbance rates are identical to estimates of land-cover change, usually expressed as percentage of change on a per-average year basis (Lambin et al. 2003). To estimate rates of land-cover change associated with landslides at a regional scale, we added up the total area affected by landslides per triggering event, $a$, and used the total area covered by mountains, $A$, and the time period covered by the records, $t$, for which data on $a$ existed in our data base. To estimate rates of land-cover change associated with landsliding in the Sierra de Las Minas, we searched for reports estimating return times for precipitation levels of the magnitude that fell during hurricane Mitch. Meteorological data for stations in the neighborhood of the Sierra de Las Minas show that the $1998 \mathrm{cu}-$ mulative October precipitation levels were large as compared to the cumulative October mean estimated over a 10-yr-period (Albores station: $705 \mathrm{~mm}$ vs. $208 \mathrm{~mm}$ and Coban station: $529 \mathrm{~mm}$ vs. 242; http://www.insivumeh.gob.gt/principal/alertas.htm). Yet, the quality of the data did not allow Lopez (1999) to estimate return times for precipitation levels of Mitch's magnitude in Guatemala. Instead, 
the author used historical data on hurricanes and concluded that "large meteorological events capable of producing major disasters occur every twenty years." Not all hurricanes are associated with large precipitations; so we made use of calculations from Nicaragua on return times for cumulative monthly precipitations, such as those that fell in October during passage of hurricane Mitch. These calculations based on Gumbel's probability distribution for extreme events showed that the return times for the unusual October cumulative precipitations varied between 75 and $500 \mathrm{yr}$ depending on site (INETER 1998). We used these figures in our estimates for the Sierra de Las Minas, acknowledging the enormous variability that this variable can take in space.

\section{RESULTS}

We identified five landforms corresponding to mountainous terrain: hills and low, mid-altitudinal, high, and very high mountains (Table 1). These landforms cover $1,576,347 \mathrm{~km}^{2}$, or equivalently 64 percent of the total area of M-CA. Mid-altitudinal mountains covered the largest area, followed by low mountains and hills (Table 1). Of an estimated population of $121,616,489,76$ percent live in mountainous terrain as defined above. Mid-altitudinal mountains harbor the largest percentage of the population, followed by high and low mountains (Table 1).

REGIONAL IMPACT OF LANDSLIDES ON LAND-COVER.-At least 62 landslide-triggering events in the last $110 \mathrm{yr}$ (1888-1998) have affected the mountains of M-CA (Fig. 1a; Appendix); 56 of these correspond to earthquakes and 6 to storms. Data on the total area covered by landslides ( $a$ in Eq. (1)) were available for 17 triggering events (14 earthquakes and 3 storms) and ranged between 300 and 38,300 ha per event (Fig. 1a; Appendix). Adding up the total area covered by landslides yields a figure of $>136,200$ ha of land transformed by landslides. This is a minimum figure, since we lack information on total area covered by landslides for the remaining 45 triggering events (Fig. 1a). The ecosystems more heavily impacted by landslides, whether we look at the number of triggering events or total area affected by landslides, were the Tropical/Subtropical Moist Broadleaf, followed by the Tropical/Subtropical Coniferous forests (Table 2). Since all but one event (El Triunfo Biosphere Reserve,
TABLE 2. Major ecosystem types affected by landslides in Mexico-Central America. Information on ecosystem type was obtained for the mapped earthquake epicenters.

\begin{tabular}{lcc}
\hline Ecosystem type & $\begin{array}{c}\text { Number of } \\
\text { landslide-triggering } \\
\text { events }\end{array}$ & $\begin{array}{c}\text { Total area } \\
\text { affected by } \\
\text { landslides (ha) }\end{array}$ \\
\hline $\begin{array}{l}\text { Tropical/Subtropical moist } \\
\text { broadleaf forest }\end{array}$ & 33 & $>119,310$ \\
$\begin{array}{l}\text { Tropical/Subtropical dry } \\
\text { broadleaf forest }\end{array}$ & 11 & \\
$\begin{array}{l}\text { Tropical/Subtropical } \\
\text { coniferous forest }\end{array}$ & 18 & $>7949$ \\
$\begin{array}{l}\text { Deserts and xeric shrublands } \\
\text { Unknown }\end{array}$ & 2 & $>8830$ \\
Total & 1 & $\mathrm{NA}$ \\
\hline
\end{tabular}

Mexico) for which information on total area covered by landslides are located in Central America, we base our estimates of landcover change on the mountains of CA for the time period covered by the records (110 yr) (Fig. 1a; Appendix). We kept El Triunfo in our calculations due to its proximity to Guatemala, and more importantly its geological relationship with the rest of CA. Based on the above considerations, at least 0.00317 percent of land/yr, or 0.317 percent of land/century, is being affected at any given time by landslides.

LOCAL IMPACT OF LANDSLIDES ON LAND-COVER.-The different image treatments used to identify landslides yielded overall accuracy values ranging between 75 and 91 percent, and overall kappa values between 0.500 and 0.825 (Table 3, Fig. 3), suggesting differences among the treatments in terms of their ability to correctly discriminate landslide from nonlandslide pixels. In general, the supervised classifications of the homogeneous (TESMAF) landscape yielded better results than the heterogeneous (PSR) one, as indicated by the higher overall accuracy and kappa values (Table 3). For the homogeneous landscapes, the supervised classification that combined NDVI with Texture for bands 1 and 2 showed the highest overall

TABLE 3. Results of a supervised image classification for detecting landslides in the Sierra de Las Minas, Guatemala. Two Landsat TM images taken within 20 mo of Hurricane Mitch were used to evaluate the performance of automated image analysis in the detection of landslides. Producers (PA), users (UA), and overall (OA) accuracy. The heterogeneous landscape included six ecosystem types, whereas the homogeneous landscape one, the Tropical evergreen seasonal mixed altimontane forest.

\begin{tabular}{|c|c|c|c|c|c|c|c|c|c|c|}
\hline & \multicolumn{5}{|c|}{ Heterogeneous landscape } & \multicolumn{5}{|c|}{ Homogeneous landscape } \\
\hline & $\mathrm{PA}(\%)$ & UA (\%) & $\mathrm{OA}(\%)$ & Карра $(\kappa)$ & Overall kappa $\kappa$ & PA (\%) & UA (\%) & $\mathrm{OA}(\%)$ & Карра $(\kappa)$ & Overall kappa $\kappa$ \\
\hline NDVI, Texture 1 and 2 & 97 & 66 & 82 & 0.485 & 0.640 & 94 & 88 & 91 & 0.774 & 0.825 \\
\hline $2,4,5,5 / 7,5 / 4,3 / 1$ & 100 & 79 & 89 & 0.648 & 0.787 & 97 & 76 & 87 & 0.607 & 0.740 \\
\hline
\end{tabular}


accuracy and kappa values (Table 3, Fig. 3b). The lowest values corresponded to the classification that used all spectral bands over the heterogeneous landscape (Table 3, Fig. 3a).

The supervised classification of the two Landsat TM images using bands 2, 4, 5, and the mineral composite applied over each forest type showed that approximately 1765 ha of land in the Sierra de Las Minas were impacted by landslides triggered in 1998 by Hurricane Mitch (Table 4). Some ecosystems were affected more than others by landslides, with the Tropical evergreen seasonal mixed upper-montane and altimontane forests exhibiting the largest impact (866 and 498 ha of forest affected by landslides; or 1.3\% and $1.1 \%$ of their area; Table 4). Using the total area affected by landslides shown above, we estimated disturbance rates between 0.194 percent/century (return time of $500 \mathrm{yr}$ ) and 1.290 percent/century (return time of $75 \mathrm{yr}$; see Methods).

\section{DISCUSSION}

Mountains are a prevalent feature of Mexican and Central American landscapes, and they currently harbor most of the population reported for this region. More importantly, for the first time, historical and remotely sensed data are combined to examine the contribution of landsliding to land-cover change in tropical and subtropical mountains. This opens the possibility for investigating the largescale dynamics of these ecosystems, including possible interactions between landsliding, a natural process modeling mountains worldwide, and deforestation.

LANDFORMS AND HUMAN POPULATION.-The proportion of land covered by mountains in M-CA (64\%) is not only greater than other estimates for the same region (44\%) (Kapos et al. 2000), but also global figures showing that mountains represent 20-36 percent of the Earth land surface (Denniston 1995, Kapos et al. 2000, Meybeck et al. 2001). In addition, we show that 76 per-

TABLE 4. Sierra de Las Minas forest types showing the area affected by landslides.

\begin{tabular}{lcc}
\hline Forest type & Total area (ha) & $\begin{array}{c}\text { Area in } \\
\text { landslides (ha) }\end{array}$ \\
\hline $\begin{array}{l}\text { Tropical evergreen } \\
\text { broad-leaved submontane } \\
\text { forest }\end{array}$ & 19,015 & 0 \\
$\begin{array}{l}\text { Tropical evergreen seasonal } \\
\text { mixed submontane forest }\end{array}$ & 18,878 & 145 \\
$\begin{array}{l}\text { Tropical evergreen seasonal } \\
\text { mixed lower-montane forest }\end{array}$ & 32,900 & 255 \\
$\begin{array}{l}\text { Tropical evergreen seasonal } \\
\text { mixed upper-montane forest }\end{array}$ & 66,829 & 866 \\
$\begin{array}{l}\text { Tropical evergreen seasonal } \\
\text { mixed altimontane forest }\end{array}$ & 44,004 & 498 \\
$\begin{array}{l}\text { Total } \\
\text { Tot }\end{array}$ & 181,626 & 1,764 \\
\hline
\end{tabular}

cent of the population of M-CA live in hills and mountains, which contrasts with global estimates indicating that between 10 and 39 percent of the world population live in similar areas (Denniston 1995, Meybeck et al. 2001). The figures for M-CA reflect in part the location of the densely populated capitals and main cities of this region in hills and mountains. While the M-CA human population living in hills and mountains derive direct benefits from them, the remaining fraction occupying the lowlands receives indirect benefits, such as those represented by hydropower and water production.

Current patterns of human occupation of Mexican-Central American mountains are interesting in three ways. First, archeological evidence indicates that prior to the arrival of Europeans, the lowlands and rugged lowlands sustained higher population densities than mountains contrary to what we see today (Culbert \& Rice 1991, Dunning 1992). Second, there has been a dramatic overall increase of population size in M-CA (Denevan 1992). Thirdly, the pattern observed in M-CA is opposite to what is found in temperate regions where cities occur mostly in the lowlands and rugged lowlands, a trend that is currently being reinforced as people abandon the mountains (Piussi 2000). In M-CA then, patterns of human occupation may have two major consequences. On one hand, it increases the vulnerability of people and their infrastructure to landsliding. On the other, it opens up the possibility for interactions between landsliding and human activities at a variety of scales.

LANDSLIDING AND LAND-COVER CHANGE.-We estimated that 0.31 percent/century of land is transformed by landslides in CA, and 1.29 percent/century in the Sierra de Las Minas. Globally, rates of land-cover change associated with landsliding are estimated at 8.2 \pm 4.8 percent $(N=5)$ and $1.6 \pm 1.0$ percent/century $(N=4$ mean $\pm \mathrm{SD}$ ) for earthquake- and precipitation-triggered landslides, respectively (Wright \& Mella 1963, Simonett 1967, Pain \& Bowler 1973, Gardwood et al. 1979, Veblen 1979, Guariguata 1990, Peterson et al. 1993, Dalling \& Iremonger 1994, Restrepo et al. 2003). Whereas our estimate of 0.31 percent/century for CA falls below these figures, that of 1.29 percent/century for the Sierra de Las Minas is within the range for rainfall-triggered landslides. A comparison with global rates of deforestation in tropical areas $(0.60 \pm$ $0.20 \mathrm{percent} / \mathrm{yr}$ or $60 \pm 20 \mathrm{percent} /$ century) (Achard et al. 2002, Lambin et al. 2003) and the mountains of Central America (range 2.3-4.0 percent/yr or 230-400 percent/century; Ochoa-Gaona \& Gonzalez-Espinosa 2000, Nagendra et al. 2003, Solorzano et al. 2003) show that disturbance rates by landsliding are below those resulting from deforestation. These differences are not surprising, given that rates of land-cover change associated with deforestation and landsliding are estimated over vastly different time scales. In particular, rates of deforestation are estimated over short periods of time in regions undergoing accelerated changes in land cover and land use. Recent studies, however, have shown that deforestation is highly variable in space and time due to the complex dynamics of human socioeconomic activities, and that over long periods of time, deforestation rates can be reversed to yield secondary forests over vast areas (Grau et al. 2003). 
The spatial and temporal extent of our data base, including its completeness, clearly had a major effect on the resulting estimates of land-cover associated with landsliding. These estimates are likely to improve as we obtain critical information for each event reported in our data base. In particular, landsliding events triggered by rainfall are underrepresented in this data base, and those triggered by earthquakes lack information on the total area covered by landslides ( $a$ Eq. (1); Appendix). In this latter case, it is possible to build a model relating earthquake magnitude with $a$, to predict total area covered by landslides for events from which this information is lacking. Using data from Costa Rica, we found a good correlation between these two variables (C. Restrepo, pers. obs.), but certainly, more data is needed to see if this model applies to larger areas. Similar models exist for total area over which landslides are triggered, that is, the area encompassing the farthest observed landslide ( $A$ in Eq. (1); Appendix) (Bommer \& Rodriguez 2002) and volume of soil and bedrock removed (Keefer 1994).

The SierRa DE LAS Minas.-The uncertainties surrounding our regional estimates of land-cover change associated with landslides reflect the scarcity of information on total area covered by landslides, $a$, associated with each triggering event. In Central America, this information has been obtained in two ways: assigning known areas of land to a few landslide percent damage classes (Mora \& Mora 1994) and mapping landslides using aerial photographs (e.g., Harp et al. 1981). Whereas the first approach allows a quick, inexpensive, but rough estimate of total area covered by landslides, the second offers a slow, expensive, and precise method.

The automated classification of remotely sensed data has the potential to bridge the gap between the two approaches mentioned above, providing in addition baseline data for future studies on landcover change, as shown by our work in the Sierra de Las Minas. We found that the use of NDVI with Texture for bands 1 and 2 yielded very good results for locating landslides, but it excluded the interior of big landslide from the calculations of landslide area, because the latter were sufficiently homogenous, and thus not enhanced by the texture filter. On the other hand, the use of bands 2, 4, 5, and the mineral composite was helpful for differentiating subtle variations between landslides and spectrally similar features such as exposed soils in recent and old fire scars, and land with reduced vegetation cover but it required several iterations to refine the classification. We suggest that a classification based on NDVI with Texture for bands 1 and 2 could be used in cases in which landslide mapping needs to be done fast and over vast areas, and/or to segment the original images and then run a new classification, using bands 2, 4, 5 , and the mineral composite to obtain good estimates of landslide area.

At least two additional issues need to be evaluated before we can make extensive use of remotely sensed data to investigate the contribution of landsliding to the large-scale dynamics of tropical and subtropical montane ecosystems. First, the topographic normalization of the images can help eliminate the uneven illumination of the slopes that is characteristic of complex terrain (Riaño et al. 2003), therefore allowing the identification of landslides and other valuable features in slopes that are shadowed. Second, an investi- gation of remotely sensed data with different spatial and temporal resolutions can help characterize better the size distribution of landslides (Stark \& Hovius 2001), and therefore the total area covered by landslides ( $a$ in Eq. (1)), as well as their spatial attributes. In addition, in combination with field studies it may help understand changes in the spectral signature of landslides in response to the recovery of plants and soil.

THE LARGE-SCALE DYNAMICS OF M-CA MONTANE ECOSYSTEMS MEDIATED BY LANDSLIDING AND CONSERVATION IMPLICATIONS.- At least 0.31 percent of M-CA montane ecosystems are in an early stage of succession each century as a result of the formation of landslides, some ecosystems being more influenced than others by this process (Table 2). Although this figure is low when compared with deforestation rates, it is important to realize that landsliding influences ecosystems in ways that are qualitatively and quantitatively different from deforestation. First, changes in land cover associated with landsliding are abrupt and often extensive. In M-CA, for example, a single earthquake or storm can remove the equivalent of 120 to 38,400 ha of forest at once, in areas ranging from 1500 to $1,600,000$ ha (Appendix). Second, a single triggering event can generate hundreds to thousands of "patches" of bare ground that differ greatly in size and upon which ecosystems, including soil, will develop. In fact, a diverse array of organisms thrive in these new substrates, and these together with the variability in patch size may explain the elevated levels of diversity found in tropical and subtropical mountains (Burger 1980, Gentry 1992). Third, the removal of both vegetation and soil, and its mobilization and deposition along the hillslope-fluvial interface may play an unappreciated role in biogeochemical cycles. For example, when landslides occur, the organic carbon in the vegetation and soil is transferred to the hillslopefluvial interface, where it can remain stored for hundreds to thousands of years (Kelsey 1982). Meanwhile, in the landslide scars, new carbon is fixed while ecosystems undergo succession (Zarin \& Johnson 1995a; Restrepo et al. 2003). To date, however, the landscape-level consequences of this rich dynamics remains poorly understood.

Unfortunately, population growth in these areas may be threatening the process of landsliding itself, and therefore our ability to understand the role it plays in these ecosystems. First, land-cover/land use (Glade 2003) and climate change (Thomas \& Thorp 1995, Diez et al. 1996) may influence the frequency and magnitude of landsliding. Second, landsliding is a complex process controlled by climatic, geologic, and biotic attributes that are highly variable in space. This variability is currently represented in a limited way in the few protected areas of M-CA. In recent years, El Triunfo Biosphere Reserve in southern Mexico, the Sierra de Las Minas Biosphere Reserve in eastern Guatemala, and La Amistad Biosphere Reserve in Costa Rica/Panama among others have been struck by earthquakes and storms that have triggered thousands of landslides. In some instances, the impact was so extensive both on the hillslopes and fluvial systems that people referred to them as major "ecological disasters," prompting plans of reforestation and management of individual landslides. Surprisingly, the ecological knowledge gained from these events was extremely limited. These protected areas may 
give us a unique opportunity to understand the process of landsliding, and at the same time to conserve this threatened process. In a region like M-CA, where earthquakes and storms are common, the combination of historic, remotely sensed, and field data will ultimately help us understand the large-scale dynamics of mountain ecosystems mediated by landsliding.

\section{ACKNOWLEDGMENTS}

The authors would like to extend their gratitude to E. Helmer, A. Sanchez, and three anonymous reviewers for their valuable comments and suggestions, and to C. Gacke and L. R. Pericchi for answering many questions. Funding for this work was provided through NSF-HRD-CREST (0206200) and NSF-Phase V of the Puerto Rico Experimental Program to Stimulate Competitive Research (PR-EPSCoR).

\section{LITERATURE CITED}

Achard, F., H. D. Eva, H. J. Stibig, P. Mayaux, J. Gallego, T. Richards, and J.-P. Malingreau. 2002. Determination of deforestation rates of the world's humid tropical forests. Science 297: 999-1002.

BLodgetT, T. 1998. Erosion rates on the NE escarpment of the Eastern Cordillera, Bolivia derived from aerial photographs and Thematic Mapper images. Ph.D. Dissertation, Cornell University, Ithaca, New York.

BOMMER, J. J., AND C. E. RODRIGUEZ. 2002. Earthquake-induced landslides in Central America. Eng. Geol. 63: 189-220.

Bucknam, R. C., J. A. Coe, M. M. Chavarria, J. W. Godt, A. C. Tarr, L. A. Bradley, S. Rafferty, D. Hancock, R. L. Dart, and M. L. Johnson. 2001. Landslides triggered by hurricane Mitch in Guatemala-Inventory and discussion. USGS Open File Report 01443.

BURGER, W. C. 1980. Why are there so many kinds of flowering plants in Costa Rica? Brenesia 17: 371-388.

BURGI, M. 2004. Driving forces of landscape change-Current and new directions. Landsc. Ecol. 19: 857-868.

Carranza, E. J. M., AND M. Hale. 2002. Mineral imaging with Landsat Thematic Mapper data for hydrothermal alteration mapping in heavily vegetated terrane. Int. J. Remote Sens. 23: 4827-4852.

CHAVEZ, P. S. 1988. An improved dark-object subtraction technique for atmospheric scattering correction of multispectral data. Remote Sens. Environ. 24: 459-479.

CIESIN, IFPRI, AND WRI. 2000. Gridded Population of the World (GPW), Version 2. Center for International Earth Science Information Network (CIESIN), Columbia University; International Food Policy Research Institute (IFPRI), World Resources Institute (WRI), Palisades, New York.

Congalton, R. G., AND K. GREEN. 1999. Assessing the accuracy of remotely sensed data: Principles and practices. Levis Publishers, New York, New York.

CulberT, T. P., AND D. S. Rice (Eds.). 1991. Precolumbian population history in the Maya Lowlands. University of New Mexico Press, Albuquerque, New Mexico.

DAI, F. C., C. F. LEE, AND Y. Y. NGAI. 2002. Landslide risk assessment and management: An overview. Eng. Geol. 64: 65-87.

Dalling, J. W., and S. Iremonger. 1994. Preliminary estimate of landslide disturbance in the Blue Mountains, Jamaica. Caribb. J. Sci. 30: 290-292.

DARWIN, S. P., AND A. L. WELDEN (Eds.). 1992. Biogeography of Mesoamerica. In Proceedings of a Symposium, Merida, Yucatan, Mexico, October 26-30, 1984. Tulane, New Orleans.
Denevan, W. M. (Eds.). 1992. The native people of the Americas in 1492. University of Wisconsin Press, Madison, Wisconsin.

DenNiston, D. 1995. High priorities: Conserving mountain ecosystems and cultures. Worldwatch Institute, Washington, DC.

Diez, A. G., L. Salas, J. R. D. De Teran, and A. Cendreno. 1996. Late quaternary climate changes and mass movement frequency and magnitude in the Cantabrian region, Spain. Geomorphology 15: 291-309.

Dunning, N. P. 1992. Lords of the hills: Ancient Maya settlements in the Puuc region, Yucatan, Mexico. Monogr. World Archaeol. 15: 1-303.

Ferrusquia-Villafranca, I. 1993. Geology of Mexico: A Synopsis. In T. P. Ramamoorthy, R. Bye, A. Lot, and J. Fa (Eds.). Biological diversity of Mexico: Origins and distribution, pp. 3-107. Oxford University Press, New York, New York.

Figueroa, E., G. Oviedo, V. C., R. Sierra, H. Balslev, J. Torres, A. Carrasco, and T. DE VRIES. 1987. Evaluacion de impacto ambiental del sismo en la Amazonia. Fundacion Natura, Quito.

GARDWOOD, N., D. P. JANOS, AND N. BROKAW. 1979. Earthquake-caused landslides: A major disturbance to tropical trees. Science 205: 997-999.

GeNTRY, A. H. 1992. Tropical forest diversity: Distributional patterns and their conservational significance. Oikos 63: 19-28.

GLADE, T. 2003. Landslide occurrence as a response to land use change: A review of evidence from New Zealand. Catena 51: 297-314.

Grau, H. R., T. M. Aide, J. K. Zimmerman, J. R. Thomlinson, E. Helmer, AND X. ZOU. 2003. The ecological consequences of socioeconomic and land-use changes in postagriculture Puerto Rico. Bioscience 53: 11591168.

Guariguata, M. 1990. Landslide disturbance and forest regeneration in the upper Luquillo mountains of Puerto Rico. J. Ecol. 78: 814-832.

Harp, E. L., R. C. Wilson, and G. F. WieCZOREK. 1981. Landslides from the February 4, 1976, Guatemala earthquake. USGS Professional Paper 1204-A.

Houghton, R. A., E. A. Davidson, And G. M. Woodwell. 1998. Missing sinks, feedbacks, and understanding the role of terrestrial ecosystems in the global carbon balance. Global Biogeochem. Cycles 12: 25-34.

INETER. 1998. Las lluvias del siglo en Nicaragua. El Huracan Mitch, las lluvias y otros eventos ciclonicos y su recurrencia en Nicaragua. Instituto Nicaraguense de Estudios Territoriales Managua, Nicaragua.

Kapos, V., J. Rhind, M. Edwards, AND M. F. Price. 2000. Developing a map of the world's mountain forest. In M. F. Price and N. Butts (Eds.). Forest in sustainable mountain development: A state of knowledge report for 2000, pp. 4-9. CAB International, Wallingford, UK.

Kappelle, M., AND A. D. Brown (Eds.). 2001. Bosques nublados del Neotropico. Editorial INBio, San Jose, Costa Rica.

KeEFER, D. K. 1994. The importance of earthquake-induced landslides to longterm slope erosion and slope-failure in seismically active regions. Geomorphology 10: 265-284.

Kelsey, H. M. 1982. Hillslope evolution and sediment movement in a forested headwater basin, Van Dusen River. USDA General Technical Report PNW-141, Portland, Oregon.

Lambin, E. F., H. J. Geist, and E. Lepers. 2003. Dynamics of land-use and land-cover change in tropical regions. Annu. Rev. Environ. Res. 28: 205-241.

LOPEZ, F. 1999. Evaluacion hidrologica de las crecidas provocadas por el paso del Huracan Mitch en Guatemala. PHI/UNESCO Montevideo, Uruguay.

Melillo, J., R. Houghton, D. Kicklighter, And A. McGuire. 1996. Tropical deforestation and the global carbon budget. Annu. Rev. Energy Environ. 21: 293-310.

Meybeck, M., P. Green, and C. VÖrÖsmarty. 2001. A new typology for mountains and other relief classes. Mt. Res. Dev. 21:34-45.

Mora, S., AND R. MORA. 1994. Los deslizamientos causados por el terremoto de Limon: Factores de control y comparación con otros eventos en Costa Rica. Revista Geológica América Central (Especial Terremoto Limón): 139-152.

Munroe, D. K., J. Southworth, And C. M. Tucker. 2002. The dynamics of land-cover change in western Honduras: Exploring spatial and temporal complexity. Agric. Econ. 27: 355-369. 
NAGendra, H., J. SOUTHWorth, AND C. M. TuCKER. 2003. Accessibility as a determinant of landscape transformation in western Honduras: Linking pattern and process. Landsc. Ecol. 18: 141-158.

OCHOA-GAONA, S., AND M. GONZALEZ-ESPinOSA. 2000. Land use and deforestation in the highlands of Chiapas, Mexico. Appl. Geogr. 20: 1742.

Olson, D. M., E. Dinerstein, E. D. Wikramanayake, N. D. Burgess, G. V. Powell, E. C. Underwood, J. A. D'amico, I. Itoua, H. E. Strand, J. C. Morrison, C. J. LoucKs, T. F. AlLnutt, T. H. RicketTS, Y. Kura, J. F. Lamoreux, W. W. Wettengel, P. Hedao, and K. R. KASSEM. 2001. Terrestrial ecoregions of the World: A new map of life on earth. Bioscience 51: 933-938.

Pain, C. F., AND J. M. Bowler. 1973. Denudation following the November 1970 earthquake. Z. Geomorphol. 18: 92-104.

Paolini, L., J. A. Sobrino, And J. C. JiméneZ-Muñoz. 2002. Detección de deslizamientos de ladera mediante imágenes Landsat TM: El impacto de estos disturbios sobre los bosques subtropicales del Noroeste de Argentina. Revista de Teledetección 18: 21-27.

Peterson, D. M., S. D. Ellen, AND D. L. KNifong. 1993. Distribution of past debris flows and other rapid slope movements from natural hillslopes in the Honolulu District of Oahu, Hawaii. USGS Open-File Report 93-514.

PICKETT, S. T. A., AND P. S. White (Eds.). 1985. The ecology of natural disturbance and patch dynamics. Academic Press, Inc., San Diego, California.

PIUsSI, P. 2000. Expansion of European mountain forests. In M. F. Price and N. Butt (Eds.). Forests in sustainable mountain development. A state of knowldge Report for 2000, pp. 19-24. CABI Publishing, Wallingford, UK.

RAJESH, H. M. 2004. Application of remote sensing and GIS in mineral resource mapping-An overview. J. Miner. Petrol. Sci. 99: 83-103.

Restrepo, C., P. VitouseK, AND P. NeVILLE. 2003. Landslides significantly alter land cover and the distribution of biomass: An example from the Ninole ridges of Hawai'i. Plant Ecol. 166: 131-143.

Riaño, D., E. Chuvieco, J. Salas, and I. Aguado. 2003. Assessment of different topographic corrections in Landsat TM data for mapping vegetation types. IEEE Trans. Geosci. Remote Sens. 41: 1056-1061.

Schimel, D. S., J. I. House, P. Bousquet, P. Ciais, P. Peylin, B. H. Braswell, M. J. Apps, D. Baker, A. Bondeau, J. Canadell, G. Churkina, W. Cramer, A. S. Denning, C. B. Field, P. Friedlingstein, C. Goodale, M. Helmann, R. A. Houghton, J. M. Melillo, B. I. Moore,
D. Murdiyarso, i. Noble, S. W. Pacala, I. C. Prentice, M. R. Raupach, P. J. Rayner, R. J. Scholes, W. L. Steffen, and C. Wirth. 2001. Recent patterns and mechanisms of carbon exchange by terrestrial ecosystems. Nature 414: 169-172.

SCHOTT, J. R. 1997. Remote sensing. The image chain approach. Oxford University Press, New York, New York.

Sidle, R. C., A. J. Pearce, AND C. L. O’Loughlin. 1985. Hillslope stability and land use. American Geophysical Union Water Resources, Washington, DC.

SimONETT, D. S. 1967. Landslide distribution and earthquakes in the Bewanni and Toricelli Mountains, New Guinea, a statistical analysis. In J. N. Jennings and J. A. Mabbutt (Eds.). Landform studies from Australia and New Guinea, pp. 64-84. Cambridge University Press, London, UK.

Solorzano, S., M. A. Castillo-Santiago, D. A. NaVArReta-Gutierrez, AND K. OYAмA. 2003. Impacts of the loss of Neotropical highland forests on the species distribution: A case study using resplendent quetzal an endangered species. Biol. Conserv. 114: 341-349.

STARK, C., AND N. HoviUs. 2001. The characterization of landslide size distributions. Geophys. Res. Lett. 28: 1091-1094.

TECSULT Foresterie Inc. 2000. Metodologia de Cartografia. Mapas de Ecosistemas Vegetales de Guatemala. Instituto Nacional de Bosques de Guatemala (INAB), World Bank Washington, DC.

THOmas, M. F. 1994. Geomorphology in the tropics. A study of weathering and denudation in low latitudes. John Wiley \& Sons, New York, New York. , AND M. B. THORP. 1995. Geomorphic response to rapid climatic and hydrologic change during the late Pleistocene and early Holocene in the humid and subhumid tropics. Quaternary Sci. Rev. 14: 193-207.

VEBLEN, T. T. 1979. Structure and dynamics of Nothofagus forests near timberline in South-Central Chile. Ecology 60: 937-945.

WeYL, R. 1980. The geology of Central America. Gebrüder Borntraeger, Berlin, Germany.

Wright, L., AND A. MelLa. 1963. Modifications to the soil pattern of South Central Chile resulting form seismic and associated phenomena during the period May to August 1960. Bull. Seismol. Soc. Am. 53: 1367-1402.

ZARIN, D. J., AND A. H. JOHNSON. 1995a. Base saturation, nutrient cation, and organic matter increases during early pedogenesis on landslide scars in the Luquillo Experimental Forest, Puerto Rico. Geoderma 65: 317-330. , AND — 1995b. Nutrient accumulation during primary succession in a montane tropical forest, Puerto Rico. Soil Sci. Soc. Am. J. 59: 14441452. 


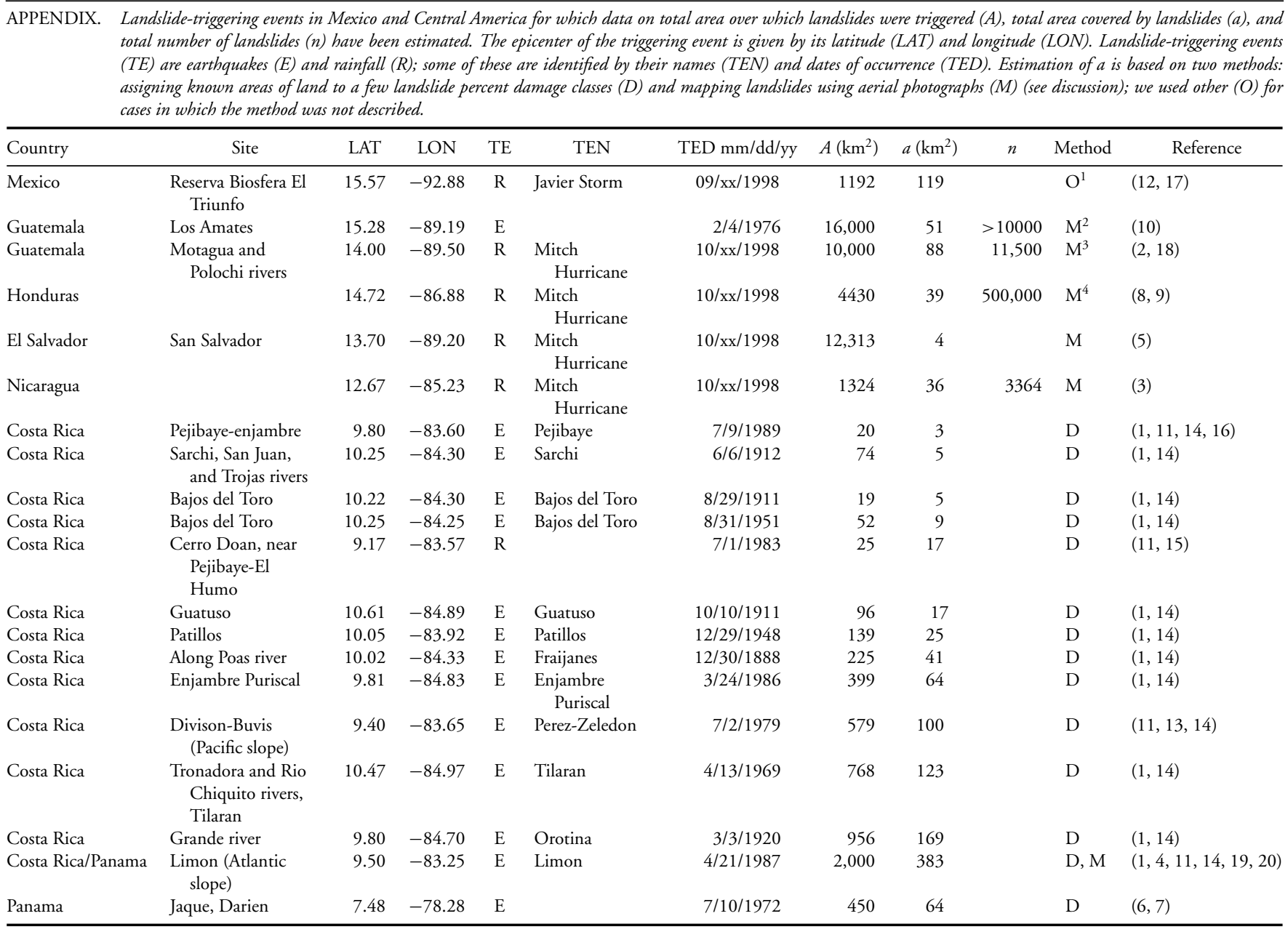

${ }^{1}$ The report states that $10-12$ percent of the El Triunfo Biosphere Reserve was affected by landslides.

${ }^{2}$ Landslides from the published maps were digitized to obtain $a$.

${ }^{3}$ This figure was derived from adding up the areas of mapped polygons, which included the source and depositional areas, including the areas damaged along the river channels.

${ }^{4}$ Landslides were mapped in this area; yet the figure on $a$ was provided by E. L. Harp (pers. comm.).

(1) BOMmer, J. J., AND C. E. RodRIGUEZ. 2002. Earthquake-induced landslides in Central America. Eng. Geol. 63: 189-220.

(2) Bucknarn, R. C., J. A. Coe, M. M. Chavarria, J. W. Godt, A. C. Tarr, L. A. Bradley, S. Rafferty, D. Hancock, R. L. Dart, and M. L. Johnson. 2001. Landslides triggered by hurricane Mitch in Guatemala. Inventory and discussion. USGS Open File Report 01-443.

(3) Cannon, S. H., K. M. Haller, I. Ekstrom, E. S. Schweig III, D. Granzell, D. W. Moore, S. A. Rafferty, and A. C. Tan. 2001. Landslide response to Hurricane Mitch rainfall in seven study areas in Nicaragua. USGS Open File Report 01-412A.

(4) CHACON, T. 1993. Estabilidad de laderas y el impacto del terremoto de Limon. B.Sc. Thesis, Universidad Nacional, Heredia, Costa Rica, 174 pp.

(5) Crone, A., R. L. Baum, D. J. Lidke, D. N. D. Sather, L. A. Bradley, and A. C. Tarr. 2001. Landslides induced by hurricane Mitch in El Salvador. An inventory and description of selected features. USGS Open-File Report 01-444.

(6) Gardwood, N. 1985. Earthquake-caused landslides in Panama: Recovery of the vegetation. Natl Geogr Soc Res Rep 21: 181-184.

(7) — D. D. JANOS, AND N. BROKAW. 1979. Earthquake-caused landslides: A major disturbance to tropical trees. Science 205: 997-999.

(8) Harp, E. L. 2001. Landslide hazards in Honduras triggered by Hurricane Mitch. Panamerican Symposium on Landslides, Cartagena, Colombia.

(9) — K. K. W. Hagaman, M. D. Held, AND J. P. McKenna. 2002. Digital inventory of landslides and related deposits in Honduras triggered by Hurricane Mitch. USGS Open Report File 02-61.

(10) — R. R. WiLSON, AND G. F. WIECZOREK. 1981. Landslides from the February 4, 1976, Guatemala earthquake. USGS Professional Paper 1204-A.

(11) Hyman, G. G. 1997. Sediment transfer in the Rio Pacuare watershed and neighboring basins of Costa Rica. Ph.D. Thesis, University of Tennessee, Knoxville, Tennessee.

(12) Instituto Nacional de ECOlogia. Tormenta Tropical Javier 1998-1999.

(13) Mora, S. 1989. Extent and socio-economic significance of slope instability in Costa Rica. In L. Harrod (Ed.). Landslides: Extent and economic significance, pp. 93-99. Balkema, Rotterdam, The Netherlands.

(14) — AND R. MORA. 1994. Los deslizamientos causados por el terremoto de Limon: Factores de control y comparación con otros eventos en Costa Rica. Revista Geológica América Central (Especial Terremoto Limón): 139-152.

(15) — R. RaldeS, AND C. RamireZ. 1989. Los deslizamientos del 2 de Julio en el Cerro Doan: Sus causas y consecuencias. Tecnologia en Marcha 9: 15-25.

(16) Red Sismologica Nacional. 1993. El Temblor de Pejibaye de Turrialba del 10 de Julio de 1993: Aspectos sismologicos, neotectonicos, y geotecnicos.

(17) SAmaniego, A. 2003. Deslaves y sus efectos de borde sobre la comunidad de roedores en un bosque mesofilo de montana. M.Sc. Thesis, Instituto de Ecologia AC, Xalapa, Veracruz, Mexico.

(18) SChUSTer, R. L., AND L. M. Highland. 2001. Socioeconomic and environmental impacts of landslides in the Western Hemisphere. USGS Open-File Report 01-0276.

(19) Vahrson, W. G., S. Laporte, G. Hernandez, AND L. Esquivel. 1992. Hydrological changes and floods related to the April 22,1991 earthquake in Limon, Costa Rica. Universidad Nacional, Facultad de Ciencias de la Tierra y el Mar, Escuela de Ciencias Geograficas.

(20) Vargas, I., G. Hyman, A. Burgos, and S. Velasquez. 1995. Los deslizamientos generados por el terremoto de Limon, 1991. Semana Cientifica II. Centro Agronomico Tropical de Investigacion y Ensenanza. 